\title{
Isolation and Characterization Montmorillonite Nanoparticles of Aceh Tamiang Bentonite as Patchouli Oil (Pogostemon cablin) Bleaching
}

\author{
TISNA HARMAWAN ${ }^{1 *}$, YULIDA AMRI $^{1}$ and TEUKU ANDI FADLLY² \\ 'Department of Chemistry, Faculty of Engineering, Universitas Samudra, Langsa, 24411, Indonesia. \\ ${ }^{2}$ Department Physics, Faculty of Engineering, Universitas Samudra, Langsa, 24411, Indonesia. \\ ${ }^{*}$ Corresponding author E-mail: tisna_harmawan@ unsam.ac.id
}

http://dx.doi.org/10.13005/ojc/350509

(Received: May 06, 2019; Accepted: September 07, 2019)

\begin{abstract}
The montmorillonite (MMT) nanoparticles as patchouli oil bleaching has been prepared from the isolated MMT of Aceh Tamiang bentonite. MMT in bentonite powder was isolated through a top-down isolation method by ultrasonication, sedimentation and high energy milling process. As many as $14 \%$ of MMT was successfully isolated and characterized via XRF and XRD. XRF analysis on the composition of isolated MMT indicated that the major composition of MMT are Si $(24.76 \%)$ and $\mathrm{Al}(16.37 \%)$. From XRD pattern, the two theta (20) peak of MMT are about $19.85^{\circ}, 20.30^{\circ}, 26.62$ and $50.15^{\circ}$ that was identified as MMT (empirical formula $\left(\mathrm{Si}_{7.80} \mathrm{Al}_{1.72} \mathrm{Cs}_{0.16} \mathrm{Fe}_{0.20} \mathrm{Mg}_{0.28} \mathrm{O}_{20.00}\right)$ ), indicating the success of the isolation process. Furthermore, based on the results calculated using XRD with Scherer's equation, the size of MMT was $0.42 \mathrm{~nm}$ and the derived lattice constant was $4.20 \AA$. . Moreover, the MMT nanoparticles exhibited as a good Patchouli oil (Pogostemon cablin), Bleaching material to reduce colors in oil.
\end{abstract}

Keywords: Bentonite, Montmorillonite, Nanoparticles, Patchouli oil (Pogostemon cablin), Advanced material, Aceh Tamiang (city).

\section{INTRODUCTION}

Patchouli oil (Pogostemon cablin) is a volatile oil and widely used in industry as flavor concentrates. The markets value of patchouli oil is largely but it's determined by the quality of the oil and the levels of major components, i.e Patchouli alcohol. Patchouli oil in Indonesia is still mostly cultivated by the common people so that the oil produced does not fulfill quality specified by the international or local standard. The essentials oil produced by farmer usually mixed with metal come from distillation equipment which made of ex-drum, thus contaminate quality of the oil. Thus, if it does not fulfill the quality requirements, the market value of the oil will be much cheaper. Some research indicates that the purification and bleaching process used MMT can improve the quality of the oil, especially in terms of color, physicochemical properties and levels of its major component ${ }^{1}$.

Montmorillonite (MMT) is one of the smectite group minerals, which has commonly

This is an Open Access article licensed under a Creative Commons license: Attribution 4.0 International (CC- BY). Published by Oriental Scientific Publishing Company @ 2018

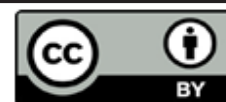


found in bentonite and composed of an octahedral sheet sandwiched between 2 tetrahedral sheets ${ }^{2-4}$. MMT is a mineral that is of concern and valuable mineral. MMT is widely used in various industrial applications because it has a high aspect ratio, morphology in plate form, its content is abundant and only requires low costs in the processing process ${ }^{5}$. For the long-term, MMT has an essential role in industrial development and various dimensions of benefits, including increasing the added value and competitiveness of Indonesia's natural resources, reducing dependence on imported products and increasing local mineral content ${ }^{6-8}$.

Aceh is an area that contains a lot of bentonite which reaches 2.6 billion tons and its distribution is in several districts in the Aceh region which until now have not been used optimally,10. Therefore, it is necessary to process Aceh Tamiang bentonite into MMT nanoperticles and find out its characteristics. To get a homogeneous MMT nanoperticles, the right material processing techniques are needed ${ }^{11-13}$. The high content of MMT in bentonite can be used as a source of MMT which can then be used for filters that serve as a bleaching Aceh patchouli oil and is sustainability.

\section{MATERIAL AND METHODS}

\section{Materials}

Aquades, purchased from Merck \& Co (Jakarta, Indonesia) and Aceh Tamiang bentonite.

\section{Methods}

Isolation of MMT from Aceh Tamiang bentonite

A total of $50 \mathrm{~g}$ of Aceh Tamiang Bentonite Powder with a size of 250 mesh was added in a beaker glass, then 2 litres aquades was added and given the ultrasonic waves for 15 min with a power of 750 watt. Prepared bentonite then dispersed at ambient temperature for equilibrium (ca. 3 days) to swell all the clay minerals. The bentonite solution was poured into a filtration tank and gently stirred at a rate of $60 \mathrm{rpm}$. Particles left on the filtration tank were discarded and all the filtered solution was controlled. The filtered solution was then centrifuged twice. The supernatant solution was collected and dried by freeze-drying at -40 for 3 days ${ }^{5,14}$. The dried powder was identified as pure MMT. The element component of MMT was examined by XRF and crystallinity test of MMT by XRD.

\section{Preparation and characterization of MMT nanoparticles}

Preparation of MMT nanoparticles was carried out using Herzong with High Energy Milling (HEM) method to reduce particle size by collision, sliding and milling processes with rotation time was 30 hours. Furthermore, the size of milled MMT was determined by XRD with Scherer's equation.

\section{RESULTS AND DISCUSSION}

\section{Isolation and characterization MMT nanoparticles from Aceh Tamiang bentonite}

MMT powder was obtained from bentonite after going through several stages such as sieving, ultrasonication, fractionation and purification. Fifty grams of Aceh Tamiang Bentonite Powder produced $7 \mathrm{~g}$ of MMT (14\% of the initial mass of Aceh Tamiang Bentonite powder). Isolated MMT characterized using XRF and XRD.

\section{X-Ray Fluorescence (XRF)}

Based on the result of XRF analysis on the composition of MMT (Fig.1 and Table 1) indicated that the major composition of MMT are $\mathrm{Si}(24.76 \%)$ and $\mathrm{Al}$ (16.37\%). MMT (empirical formula $\left(\mathrm{Si}_{7.80} \mathrm{Al}_{1.72}\right.$ $\left.\mathrm{Cs}_{0.16} \mathrm{Fe}_{0.20} \mathrm{Mg}_{0.28} \mathrm{O}_{20.00}\right)$ ) is a recalcitrant clay mineral with fine grain.

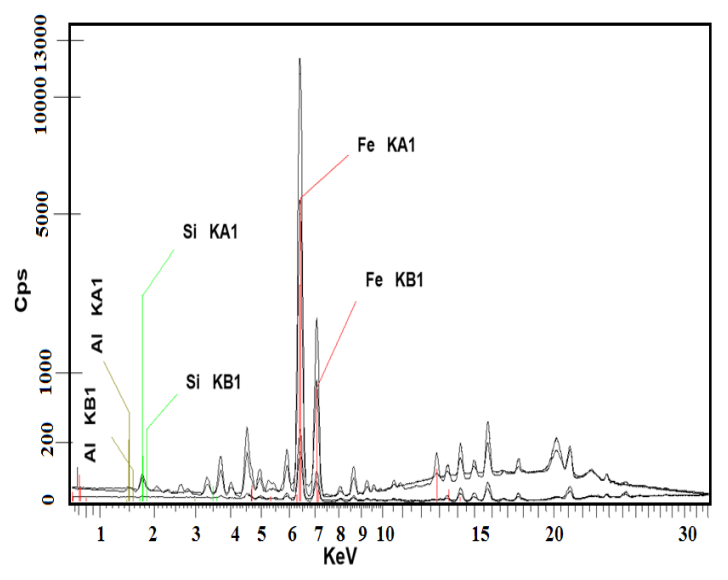

Fig. 1. The XRF result of MMT

Table 1: The composition of MMT from XRF result

\begin{tabular}{cccc}
\hline Element & Weight (\%) & Element & Weight (\%) \\
\hline $\mathrm{O}$ & 45.71 & $\mathrm{Ti}$ & 1.67 \\
$\mathrm{Si}$ & 25.04 & $\mathrm{Ca}$ & 1.49 \\
$\mathrm{Al}$ & 8.10 & $\mathrm{~K}$ & 0.79 \\
$\mathrm{Fe}$ & 14.08 & $\mathrm{~S}$ & 0.68 \\
\hline
\end{tabular}




\section{X-Ray Diffraction (XRD)}

Based on the result of XRD pattern (Fig. 2), peak list (Table 2), crystallographic parameters (Table 3 ) and the two theta $(2 \theta)$ peak of MMT (Table 4), The Present of specific point about $19.85^{\circ}, 20.30^{\circ}, 26.62$ and $50.15^{\circ}$ was identified as MMT through a XRD fingerprint databank JCPDS (Joint Committee on Powder Diffraction Standards) Card 96-901-09584-6. The size of MMT isolated from Aceh Tamiang Bentonite was successfully calculated using XRD with Scherer's equation. Based on the result, the highest intensity of the diffraction peak was taken place in (011) with a diffraction angle $2 \theta$ of $26.62^{\circ}$ and calculated particles size of MMT was $0.42 \mathrm{~nm}$ and the derived lattice constant was $4.20 \AA$ (Table 2).

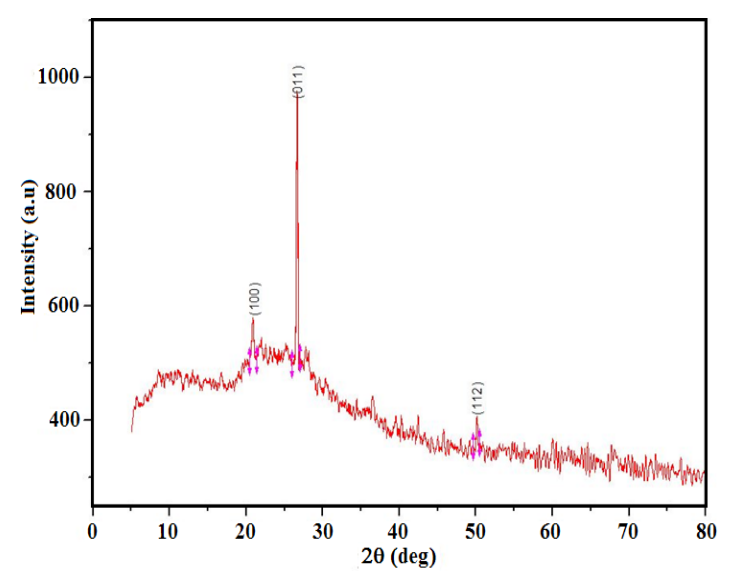

Fig. 2. XRD pattern of MMT

Table 2: Peak list of MMT

\begin{tabular}{ccccccc}
\hline $2 \theta(\mathrm{deg})$ & $\lambda(\AA)$ & $\mathrm{k}$ & $\mathrm{hkl}$ & $\mathrm{FWHM}(\mathrm{rad})$ & $\mathrm{a}(\AA)$ & $\mathrm{t}(\mathrm{nm})$ \\
\hline 20.30 & 1.5406 & 0.6 & 100 & 0.263 & 3.57 & 0.35 \\
26.62 & 1.5406 & 0.6 & 011 & 0.226 & 4.20 & 0.42 \\
50.15 & 1.5406 & 0.6 & 112 & 0.217 & 4.70 & 0.47 \\
\hline
\end{tabular}

Table 3: The Crystallographic parameters

\begin{tabular}{cc}
\hline Parameter & Information \\
\hline Crystal system & Monoclinic \\
Space group & $\mathrm{C} 12 / \mathrm{m} 1$ \\
Space group number & 12 \\
a $(\AA)$ & 5.1810 \\
b $(\AA)$ & 8.9450 \\
C $(\AA)$ & 12.3400 \\
Alpha $\left(^{\circ}\right)$ & 90.0000 \\
Beta $\left(^{\circ}\right)$ & 99.6200 \\
Gamma $\left(^{\circ}\right)$ & 90.0000 \\
Calculated density $(\mathrm{g} / \mathrm{cm} 3)$ & 1.84 \\
Volume of cell $(106 \mathrm{pm} 3)$ & 563.84 \\
RIR & 8.66 \\
\hline
\end{tabular}

Table 4: The two theta $(2 \theta)$ peak of MMT

\begin{tabular}{|c|c|}
\hline \multicolumn{2}{|c|}{ 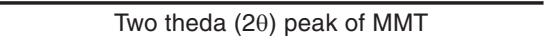 } \\
\hline Standard ${ }^{4-6}$ & Aceh Tamiang \\
\hline $7.2^{\circ}, 19.83^{\circ}, 20.27$ & $19.85^{\circ}, 20.30^{\circ}$ \\
\hline $26.51,50.30$ & $26.62^{\circ}, 50.15^{\circ}$ \\
\hline
\end{tabular}

The bleaching test

The MMT nanoparticles application to the patchouli oil was needed to know ability of MMT nanoparticles to bleach or reduce the colors of patchouli oil. In this study, MMT nanoparticles were applied to bleaching the Aceh patchouli oil and the results have been shown in Figure 3.

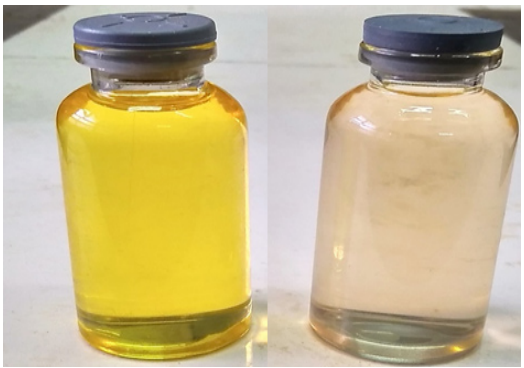

(a)

(b)
Fig. 3. The test result of MMT nanoparticles as Aceh patchouli oil bleaching

\section{CONCLUSION}

From the research that has been done, it can be concluded that the MMT from Aceh Tamiang Bentonite have been isolated as evidence by XRD, wherein the two theta $(2 \theta)$ peak of MMT are about $19.85^{\circ}, 20.30^{\circ}, 26.62$ and $50.15^{\circ}$ that was identified as MMT (empirical formula $\left(\mathrm{Si}_{7.80} \mathrm{Al}_{1.72} \mathrm{Cs}_{0.16} \mathrm{Fe}_{0.20} \mathrm{Mg}_{0}\right.$ ${ }_{28} \mathrm{O}_{20.00}$ )) in accordance with databank JCPDS (Joint Committee on Powder Diffraction Standards) Card 96-901-0958 and the size of MMT was $0.42 \mathrm{~nm}$ and the derived lattice constant was $4.20 \AA$. Aceh Tamiang bentonite produced MMT nanoparticles which has the potential as patchouli oil bleaching.

\section{ACKNOWLEDGEMENT}

The authors would like to send gratitude to the Rector of Universitas, Samudra for Grant (DIPA Universitas Samudra) towards this research in the PDM Scheme 2018.

\section{Conflicts of interest}

All authors have read and approved the manuscipt and take full responsibility for its content. The authors have no conflicts of interest in regard to this research or its funding. 


\section{REFERENCES}

1. Rihayat, T.; Marita, Y.; Wijaya, N.R.; Helmi. Seminar Nasional Unmas Denpasar., 2016 2016, 124-132.

2. Bergaya, F.; Lagaly, G. Appl. Clay Sci., 2013, 5, 1-7.

3. Meng, N.; Chu, X.; Ge, M.Q.; Zhang, M.; Sun, B.; Su, Y.T.; Zhou, N.L. Appl. Clay Sci., 2018, 162, 454-460.

4. Zhirong, L.; Uddin, M. A.; Zhanxue, S. Spectrochim Acta A., 2011, 79, 1013- 1016.

5. Lee, Y.H.; Kuo, T.F.; Lin, W.C.; Chen, B.Y.; Feng, Y.K.; Wen, Y.R.; Lin, F.H. Biomed. Eng. Appl. Basis Commun., 2005, 17(2), 72-78.

6. Cook, H. E.; Johnson, P. D.; Matti, J. C.; Zemmels, I. Initial Repts. Deep Sea Drilling Project., 1975, 38, 999-1007.

7. Dobrzanski, L.A.; Bilewicz, M.; Viana, J.C. Arch. Mater. Sci. Eng., 2012, 53, 5-28.
8. Pavlidou, S.; Papaspyrides, C.D. Prog. Polym. Sci., 2008, 33, 1119-1198.

9. Arryanto.; Yateman.; Amini, S.; Rosyid, M.F.; Rahman, A.; Artsanti, P. Ministry of Research, Technology and Higher Education of Indonesia-Press., 2007.

10. Wijaya, K.; Sugiharto, E.; Mudasir.; Tahir, I.; Liawati, I. Indones. J. Chem., 2010, 4(1), 32-42.

11. Nabok, A . Nanotechnology Series-Artech House., 2011.

12. Harmawan, T. Pemanfaatan Lignin Isolat Bahan Pengikat Alami (Natural Binder) Dari Kayu Pinus (Pinus Merkusii Jungh Et De Vriese) Sebagai Penguat Aspal. Thesis. USU-Press., 2013.

13. Totoki, S.; Wada, Y.; Moriya, N.; Shimaoka, H. Shimadzu Rev., 2007, 62, 173-179.

14. Zhou,Y.; Pervin, F.; Rangari V.K.; Jeelani, S. J. Mater Process. Technol., 2007, 347-35. 